\title{
Komplementer terápiás gyógymódok megítélése a perioperatív ellátásban dolgozó egészségügyi szakdolgozók között
}

\author{
Soós Sándor Árpád dr. ${ }^{1}$ - Jeszenôi Norbert dr..$^{3,4}$ \\ Darvas Katalin dr. ${ }^{1,2}$ - Harsányi László dr. ${ }^{1}$
}

Semmelweis Egyetem, Általános Orvostudományi Kar, ${ }^{1}$ I. Sebészeti Klinika,

${ }^{2}$ Aneszteziológiai és Intenzív Terápiás Klinika, Budapest

${ }^{3}$ Eötvös Loránd Tudományegyetem, Genetikai Tanszék, Budapest

${ }^{4}$ MTA-NAP B Molekuláris Neuroendokrinológiai Kutatócsoport, Élettani Intézet, Szentágothai Kutatóközpont,

Idegtudományi Központ Pécsi Tudományegyetem, Pécs

Bevezetés: Magyarországon az egészségügyi szakdolgozók viszonyulása a komplementer terápiás gyógymódokhoz még nem vizsgált téma. Célkitüzés: Célunk volt felmérni a Semmelweis Egyetem hat, perioperatív ellátást végző klinikáján az egészségügyi szakdolgozók ismeretét és véleményét a természetgyógyászattal kapcsolatban. Módszer: Anonim, papíralapú kérdőíves felmérést végeztünk. 82\%-os válaszadási arány mellett összesen 119 kérdőív adatait dolgoztuk fel leíró statisztikai elemzéssel és $\chi^{2}$-próbával. Eredmények: A válaszadók mindössze 25,2\%-a tartotta eléggé tájékozottnak magát, 68,1\%-uk érdeklődött és 60,5\%-uk tanulna a természetgyógyászatról. A napi munka során 70,6\%-uk szívesen alkalmazna komplementer terápiás gyógymódokat, szignifikánsan gyakrabban azok, akik saját betegség esetén is igénybe veszik e gyógymódokat $(\mathrm{p}=0,0027)$. A legnépszerúbb gyógymódok a homeopátia, az alternatív masszázs- és mozgásterápia, az akupunktúra és a manuálterápia voltak. Következtetés: A nemzetközi szakirodalommal egyezően idehaza is a vizsgálatunkban felmért szakdolgozók nyitottak és érdeklődőek a természetgyógyászattal kapcsolatban. Orv. Hetil., 2017, 158(10), 368-375.

Kulcsszavak: ápolók, sebészet, integratív orvoslás

\section{Attitudes, knowledge and use of complementary and alternative medicine among perioperative healthcare professionals}

Introduction: Perioperative healthcare professionals' attitudes towards non-conventional treatments have not been explored in Hungary yet. Aim: Our goal was to survey healthcare professionals' attitude and knowledge towards naturopathy in six clinics of the Semmelweis University that provide perioperative care. Method: An anonymous, paper-based questionnaire was used. With an $82 \%$ response rate, the data was gained from 119 questionnaires and was processed using statistical analysis and chi-squared test. Results: Only 25.2\% of those surveyed considered themselves to be well-informed in this field. $68.1 \%$ of the participants had an interest in naturopathy and $60.5 \%$ would have liked to learn about naturopathy. $70.6 \%$ would be willing to use non-conventional treatments in their daily work, predominantly those who have used these methods in the case of their own illness, $p=0.0027$. The most popular treatment methods included homeopathy, alternative massage and movement therapy, acupuncture and manual therapy. Conclusion: As anticipated based on international literature in this field, those Hungarian healthcare professionals who took part in our survey showed openness and interest towards naturopathy.

Keywords: nurses, surgery, integrative medicine

Soós, S. Á., Jeszenői, N., Darvas, K., Harsányi, L. [Attitudes, knowledge and use of complementary and alternative medicine among perioperative healthcare professionals]. Orv. Hetil., 2017, 158(10), 368-375.

(Beérkezett: 2016. november 11.; elfogadva: 2016. december 28.) 


\section{Rövidítések}

ASA = American Society of Anesthesiologists; CAM = complementary and alternative medicine; $\mathrm{CI}=$ konfidenciaintervallum; EBM = evidence-based medicine; $\mathrm{ENKK}=$ Egészségügyi Nyilvántartási és Képzési Központ; OR = odds ratio; PONV = posztoperatív hányinger és hányás

A Magyar Tudományos Akadémia Orvosi Tudományok Osztálya által 2004-ben és 2010-ben kiadott állásfoglalás szerint: „A komplementer és alternatív medicina kifejezés azokat a gyógyító és diagnosztikus eljárásokat foglalja öszsze, amelyek nem részei a hagyományos, konvencionális, nyugati orvostudománynak" [1]. Jogszabályilag e módszereket a 40/1997. (III. 5.) kormányrendelet definiálja mint olyan egészségügyi tevékenységet, ,amely a konvencionális gyógyítási módszereket kiegészíti, meghatározott esetekben helyettesíti”. E módszerek eltérő szemléletmódját az 1997. évi CLIV., egészségügyről szóló törvény így írja le: „A nem konvencionális eljárások az egészség és betegség eltérő szemléletén, a konvencionális, természettudományosan megalapozott eljárásoktól eltérő megközelítésből eredő módszereken alapulnak." Cikkünkben a hazai, elfogadott megnevezéseknek megfelelően a „komplementer”, „nem konvencionális” és „természetgyógyászat" megnevezéseket szinonimaként alkalmazzuk.

A komplementer terápiás gyógymódok (CAM) világszerte népszerú és gyakran használt módszerek [2-5]. Ezeknek az alkalmazása értelmezhető az egészségtudatosság egyik jeleként, azonban a jelenség óvatosságra is int: gyaníthatóan egyre több kórházba kerülő, akár kritikus állapotú beteg vesz igénybe ilyen gyógymódokat, amiről az esetek többségében nem számol be kezelőorvosának [6]. Nem hagyható ez a tendencia figyelmen kívül a perioperatív ellátásban sem, amikor a különböző kezelések, elsősorban a gyógynövény-terápia nem várt és nehezen kiszámítható interakciói a szokásosnál is nagyobb jelentőséggel bírnak [7-9]. Figyelemre méltó, hogy az American Society of Anesthesiologists által egy betegek számára kiadott tájékoztató arra figyelmeztet, hogy a lehetséges interakciók miatt a tervezett mútétek előtt két héttel a páciensek ne alkalmazzanak fitoterápiát [10].

A betegek a legtöbbet az ápolószemélyzettel vannak kapcsolatban ellátásuk során, így a növekvó igényekre tekintettel fontos lenne az egészségügyi szakdolgozók képzésében is helyet adni a komplementer terápiás gyógymódok legalább alapszintű ismeretének, hiszen ennek hiányában a témában tájékozott betegekkel szemben egyenlőtlen helyzetben vannak, s kommunikációjuk is kárt szenvedhet. Különös jelentőséget adnak ennek a megközelítésnek azok a közlések, amelyek szerint fejlettebb egészségügyi kultúrával rendelkező rendszerekben a nővérek az átlagnál magasabb arányban használnak természetgyógyászati termékeket, tehát kifejezetten nyitottak a témára [11-13].

A szakirodalmi áttekintés során nem találtunk Magyarországon végzett, a perioperatív ellátásban dolgozó egészségügyi szakdolgozók között készült felmérést a komplementer terápiás gyógymódok ismeretéról. Felmérésünket ennek a hiányosságnak a pótlására terveztük.

\section{Módszer}

Célunk volt egy olyan vizsgálat elkészítése, amely felméri, milyen tudás birtokában vannak és milyen attitúddel rendelkeznek a perioperatív ellátásban dolgozó egészségügyi szakdolgozók a komplementer terápiás gyógymódokkal kapcsolatban.

\section{Minta}

A felmérést a Semmelweis Egyetem mútéti ellátással foglalkozó klinikáin végeztük, anonim, papíralapú kérdőíves vizsgálat formájában 2014. október-2015. december között. A kérdő́ivet az I. Sebészeti Klinika, a Transzplantációs és Sebészeti Klinika, az Aneszteziológiai és Intenzív Terápiás Klinika, az Urológiai Klinika, a Fül-Orr-Gégészeti és Fej-Nyaksebészeti Klinika, illetve az Ortopédiai Klinika szakdolgozói töltötték ki. A kiosztott 145 kérdőívből 119-et kaptunk vissza, a válaszadási arány $82 \%$-os volt.

\section{A kérdōin}

A kérdőívet tematikusan építettük fel, három fó részre osztva. Az első rész a szociodemográfiai paramétereket mérte fel: a kérdések az életkor, a munkában eltöltött évek és a végzettség-képzettség felmérésére vonatkoztak. A második részben eldöntendő kérdések vizsgálták az ápolók viszonyulását a komplementer terápiás gyógymódokhoz: kulcspontjaink az érdeklődés, a tanulási kedv és a komplementer terápiás gyógymódok alkalmazása személyes és szakmai életükben. A harmadik részben két kitöltendő táblázat szerepelt. Az első a Magyarországon nem konvencionális gyógymódok értékelését vizsgálta öt választható kategória alapján. A második az ápolók természetgyógyászattal kapcsolatos attitúdjét, a véleményüket meghatározó tényezőket vizsgálta.

\section{Statisztikai elemzés}

Az adatfeldolgozást az SPSS 20-as verziójával készítettük. A szociodemográfiai adatokat leíró statisztikával vizsgáltuk. Az ismeretek és attitúdök összefüggéseinek elemzéséhez Pearson-féle $\chi^{2}$-próbát használtunk. Szignifikánsnak a $\mathrm{p}<0,05$ szintet fogadtuk el.

\section{Etikai engedély}

A vizsgálatot a Semmelweis Egyetem Regionális, Intézményi Tudományos és Kutatásetikai Bizottság engedélyezte (SE TUKEB 142/2015). A kutatást a Helsinki Deklaráció elveinek megfelelően végeztük. 
1. táblázat

Demográfiai adatok, illetve a kitöltók viszonyulása a komplementer terápiás gyógymódokhoz $(\mathrm{n}=119$ és \%)

\begin{tabular}{ll}
\hline Életkor & 41,8 év (SD 7,713) \\
Munkatapasztalat & 21,5 év (SD 8,825) \\
Érdeklődik a CAM iránt & 381 fór érdeklődő $(68,1 \%)$ \\
& 34 fö közömbös $(28,6 \%)$ \\
& 4 fó elutasító $(3,4 \%)$ \\
Elegendő ismerettel rendelkezik a & $30(25,2 \%)$ \\
CAM-ról véleménye szerint & \\
$\begin{array}{l}\text { Szívesen tanulna CAM-t } \\
\text { Ismer megbízható természetgyógyászt, } \\
\text { akit ajánlana betegeinek }\end{array}$ & $30(25,2 \%)$ \\
$\begin{array}{l}\text { Vett már igénybe CAM-t ó vagy } \\
\text { családtagja }\end{array}$ & $66(55,5 \%)$ \\
$\begin{array}{l}\text { Fontosnak tartja, hogy tudjon a } \\
\text { betegek CAM-használatáról }\end{array}$ & $98(82,4 \%)$ \\
$\begin{array}{l}\text { Rákérdez a betegeknél a CAM } \\
\text { használatára }\end{array}$ & $45(37,8 \%)$ \\
Van természetgyógyász végzettsége & $7(5,9 \%)$ \\
$\begin{array}{l}\text { Alkalmazott már a munka során } \\
\text { CAM-t }\end{array}$ & $20(16,8 \%)$ \\
$\begin{array}{l}\text { Alkalmazna a jövőben a munka során } \\
\text { CAM-t }\end{array}$ & $84(70,6 \%)$ \\
$\begin{array}{l}\text { Támogatná az integratív medicina } \\
\text { bevezetését }\end{array}$ & $95(79,8 \%)$ \\
& \\
\hline
\end{tabular}

\section{Eredmények}

A kérdoóivet 119 szakdolgozó, a megszólítottak 82\%-a töltötte ki. A CAM ismeretével, alkalmazásával és a tanulási kedvvel kapcsolatos válaszokat az 1. táblázatban mutatjuk be.

A kitöltők nagy munkatapasztalattal rendelkeztek, átlagosan több mint 21 éve dolgoztak az egészségügyben. A komplementer medicina iránt a kitöltők több mint kétharmada érdeklődő volt, 5,9\%-uk természetgyógyászati végzettséggel is rendelkezett. A szakdolgozók több mint fele állította, ô vagy családtagjai vettek már igénybe

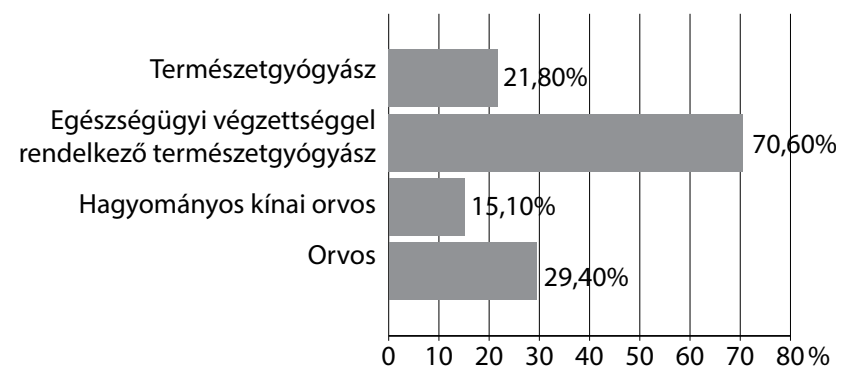

1. ábra

Az egészségügyi szakdolgozók véleménye a komplementer terápiás gyógymódok alkalmazóinak minimálisan szükséges képzettségéről

komplementer terápiás gyógymódokat. Kiemelendő, hogy ők azok tehát, akik már kipróbáltak alternatív gyógymódokat, akik szignifikánsan nagyobb eséllyel alkalmaznák ezeket a módszereket a klinikai gyakorlatban is ( $\mathrm{p}=0,0027,95 \%$-os CI 1,5067-7,8998, OR: 3,45).

A komplementer gyógymódok alkalmazásával kapcsolatban a szakdolgozók döntő többsége egészségügyi végzettséghez, kisebb részük orvosi diplomához kötné e módszerek alkalmazását (1. ábra).

A vizsgálatban az MTA idézett állásfoglalásában szereplő, illetve az ENKK mint hivatalos képzési rendszer keretei között tanulható komplementer terápiás gyógymódok ismeretére és megítélésére kérdeztünk rá (2. táblázat). A legkevésbé ismert komplementer terápiás gyógymód a neurálterápia, a szakdolgozók 71,4\%-a nem hallott még erről a módszerről. A homeopátiát értékelték a legtöbben $(26,9 \%)$ tudományosan nem megalapozott módszernek, míg az akupunktúrát és az alternatív mozgás- és masszázsterápiát vélték a legtöbben (6263\%) tudományosan megalapozott nem konvencionális gyógymódnak. Saját betegség esetén a homeopátiát vették igénybe legtöbben $(22,7 \%)$, míg a napi gyakorlatban az alternatív mozgás- és masszázsterápiát, valamint az akupresszúrát alkalmazták $(2,5-3,4 \%)$. A hatályos jogi szabályozás szerint akupunktúrát, homeopátiát, neurálterápiát és gerincoszlopot is érintő manuálterápiát csak

2. táblázat |A komplementer terápiás gyógymódok értékelése ( $\mathrm{n}=119$ és \%)

\begin{tabular}{|c|c|c|c|c|c|}
\hline & Nem ismeri & $\begin{array}{l}\text { Nem tartja meg- } \\
\text { alapozott módszernek }\end{array}$ & $\begin{array}{l}\text { Megalapozott } \\
\text { módszernek tartja }\end{array}$ & $\begin{array}{l}\text { Igénybe veszi } \\
\text { betegség esetén }\end{array}$ & $\begin{array}{l}\text { Alkalmazza } \\
\text { a gyógyításban }\end{array}$ \\
\hline Akupunktúra & $19(16 \%)$ & $9(7,6 \%)$ & $75(63 \%)$ & $16(13,4 \%)$ & \multirow{4}{*}{$\begin{array}{l}\text { Nem volt } \\
\text { választható opció } \\
\text { (lásd szöveg) }\end{array}$} \\
\hline Homeopátia & $13(10,9 \%)$ & $32(26,9 \%)$ & $47(39,5 \%)$ & $27(22,7 \%)$ & \\
\hline Neurálterápia & $85(71,4 \%)$ & $12(10,1 \%)$ & $17(14,3 \%)$ & $5(4,2 \%)$ & \\
\hline Manuálterápia & $49(41,2 \%)$ & $19(16 \%)$ & $38(31,9 \%)$ & $13(10,9 \%)$ & \\
\hline Fitoterápia & $43(36,1 \%)$ & $18(15,1 \%)$ & $42(35,3 \%)$ & $14(11,8 \%)$ & $2(1,7 \%)$ \\
\hline Alternatív mozgás- és masszázsterápia & $16(13,4 \%)$ & $8(6,7 \%)$ & $74(62,2 \%)$ & $17(14,3 \%)$ & $4(3,4 \%)$ \\
\hline Reflexológia & $26(21,8 \%)$ & $16(13,4 \%)$ & $62(52,1 \%)$ & $13(10,9 \%)$ & $2(1,7 \%)$ \\
\hline Kineziológia & $43(36,1 \%)$ & $21(17,6 \%)$ & $44(37 \%)$ & $9(7,6 \%)$ & $2(1,7 \%)$ \\
\hline Akupresszúra & $31(26,1 \%)$ & $20(16,8 \%)$ & $55(46,2 \%)$ & $10(8,4 \%)$ & $3(2,5 \%)$ \\
\hline Fülakupunktúra & $29(24,4 \%)$ & $25(21 \%)$ & $54(45,4 \%)$ & $11(9,2 \%)$ & 0 \\
\hline
\end{tabular}


orvos végezhet, így e módszerek esetében az „alkalmazom a gyógyításban” nem volt választható válasz [14].

A felmérés fontos témája volt, hogy a szakdolgozók komplementer terápiás gyógymódokkal kapcsolatos véleményét milyen szempontok alakítják (3. táblázat). Leginkább a tudományos evidenciák, a saját vagy családjuk tapasztalata és a képzési lehetóségek, míg legkevésbé a média és a kollégák véleménye határozták ezt meg.

Megvizsgáltuk, hogy a szakdolgozók természetgyógyászattal kapcsolatos tanulási kedvét mely tényezők befolyásolhatják. A tanulási kedv és az életkor kapcsolatát tekintve, 10 éves bontásban vizsgálva, a korcsoportok között nem volt szignifikáns különbség (4. táblázat). Nem találtunk szignifikáns összefüggést a szakdolgozók végzettsége és tanulási kedvük között sem (5. táblázat).

3. táblázat |A szakdolgozók véleményét meghatározó tényezők ( $\mathrm{n}=119$ és \%)

\begin{tabular}{llll}
\hline & $\begin{array}{l}\text { Jelentős szerepet } \\
\text { játszik }\end{array}$ & $\begin{array}{l}\text { Kismértékben } \\
\text { befolyásolja }\end{array}$ & $\begin{array}{l}\text { Nem } \\
\text { befolyásolja }\end{array}$ \\
\hline $\begin{array}{l}\text { Tudományos } \\
\text { evidenciák }\end{array}$ & $81(68,1 \%)$ & $22(18,5 \%)$ & $16(13,4 \%)$ \\
$\begin{array}{l}\text { Kollégák véleménye } \\
\begin{array}{l}\text { Saját vagy családtagjai } \\
\text { tapasztalata }\end{array}\end{array}$ & $31(26,1 \%)$ & $57(47,9 \%)$ & $31(26,1 \%)$ \\
$\begin{array}{l}\text { Média } \\
\begin{array}{l}\text { Több képzési } \\
\text { lehetóség }\end{array}\end{array}$ & $15(12,6 \%)$ & $43(36,1 \%)$ & $61(51,3 \%)$ \\
\hline
\end{tabular}

4. táblázat |A szakdolgozók életkora és a komplementer terápiás gyógymódokkal kapcsolatos tanulási kedv összefüggése $(n=119$ és \%)

\begin{tabular}{lcccl}
\hline Életkor (év) & Tanulna & Nem tanulna & Összesen & Szignifikancia \\
\hline $20-29$ & $2(1,7 \%)$ & $4(3,4 \%)$ & $6(5,0 \%)$ & - \\
$30-39$ & $23(19,3 \%)$ & $18(15,1 \%)$ & $41(34,5 \%)$ & 0,475139 \\
$40-49$ & $32(26,9 \%)$ & $18(15,1 \%)$ & $50(42,0 \%)$ & 0,507122 \\
$50-59$ & $13(10,9 \%)$ & $6(5,0 \%)$ & $19(16,0 \%)$ & 0,442419 \\
$60-69$ & $2(1,7 \%)$ & $1(0,8 \%)$ & $3(2,5 \%)$ & - \\
\hline
\end{tabular}

5. táblázat A szakdolgozók képzettsége és a komplementer terápiás gyógymódokkal kapcsolatos tanulási kedv összefüggése ( $\mathrm{n}=119$ és \%)

\begin{tabular}{lllll}
\hline Képzettség & Tanulna & Nem tanulna & Összesen & Szignifikancia \\
\hline $\begin{array}{l}\text { Egészségügyi } \\
\text { szakiskola }\end{array}$ & $5(4,2 \%)$ & $4(3,4 \%)$ & $9(7,6 \%)$ & - \\
$\begin{array}{l}\text { OKJ-s ápoló } \\
\text { Aneszte- }\end{array}$ & $12(10,1 \%)$ & $9(7,6 \%)$ & $21(17,6 \%)$ & 0,729034 \\
$\begin{array}{l}\text { ziológus } \\
\text { szakasszisz- } \\
\text { tens }\end{array}$ & & & & \\
$\begin{array}{l}\text { Diplomás } \\
\text { ápoló }\end{array}$ & $21(17,6 \%)$ & $8(6,7 \%)$ & $29(24,4 \%)$ & 0,131052 \\
\hline
\end{tabular}

\section{Megbeszélés}

Egészségügyi szakdolgozók között számos felmérés készült a komplementer terápiás gyógymódok megítélésével kapcsolatban a világ több országában, de Magyarországon ezzel a témával, legjobb tudomásunk szerint, még nem foglalkoztak.

\section{Vizsgálatunk korlátai}

Felmérésünknek több korlátja is volt. Először: bár több egyetemi klinika szakdolgozóit bevontuk, minthogy csak a Semmelweis Egyetem dolgozói voltak kitöltőink, monocentrikus a vizsgálat. Másrészt több mútéti szakmát - különféle megfontolások után, tudatosan - kihagytunk a felmérésből (például gyermeksebészet, szülészet-nőgyógyászat), főként speciális beteganyaguk és ebből fakadóan az eltérő és speciális ismeretek igénye miatt. Harmadsorban: bár az esetszámunk alkalmas statisztikai következtetések levonására, több kitöltővel adataink még reprezentatívabbak lettek volna.

\section{Attitüd és ismeretek}

Vizsgálatunkban talán a legfontosabb kérdés a komplementer terápiás gyógymódokkal kapcsolatos attitúd és ismeretek felmérése. Alapvető probléma, hogy az egészségügyi dolgozók, orvosok és ápolók egyaránt limitált ismeretekkel rendelkeznek a természetgyógyászati módszerekről, így a jól informált betegekkel a témáról való kommunikáció is kárt szenvedhet [15]. Bár a szakdolgozók pozitív attitüddel rendelkeznek, ismereteik hiányosak a természetgyógyászattal kapcsolatban $[16,17]$. Egy ausztrál felmérés szerint az ápolók 59\%-a pozitívan viszonyul a nem konvencionális gyógymódokhoz, 32,6\%uk közömbös, mindössze 7,2\%-uk elutasító ezzel kapcsolatban. A képzés hiányosságára mutat rá, hogy a szakdolgozók 7,8\%-a saját bevallása szerint nem ismeri, $52,5 \%$-uk pedig csekély ismerettel rendelkezik ezekről a módszerekről [18]. Egy koreai orvosok és ápolók attitüdjét összehasonlító tanulmány szerint az ápolók $72,7 \%$-a, az orvosok $57,1 \%$-a volt pozitív attitűddel a természetgyógyászattal kapcsolatban, továbbá a nővérek $67,7 \%$-a, míg az orvosok mindössze $38,8 \%$-a tartotta hatékonynak e módszereket [19].

Hazai viszonylatban a családorvosok $17,5 \%$-a, a sebészek 15,7\%-a, az aneszteziológusok 10,9\%-a, míg jelen felmérésben a szakdolgozók 25,2\%-a értékelte magát elég tájékozottnak a komplementer terápiás gyógymódokkal kapcsolatban. E felmérések szerint a sebészek 49,4\%-a, az aneszteziológusok 54,3\%-a, a szakdolgozók 68,1\%-a érdeklődónek tartotta magát a természetgyógyászattal kapcsolatban $[20,21]$. Elmondható tehát, hogy az ápolók Magyarországon is érdeklődőbbek a nem konvencionális gyógyászat iránt az orvosoknál, ám ugyanúgy kevés információval bírnak annak mikéntjéről. 


\section{A komplementer terápiás gyógymódok ajánlása és igénybevétele}

Megvizsgáltuk, hogy az egészségügyi szakdolgozók ajánlanák-e betegeiknek a nem konvencionális gyógymódokat, illetve saját maguk igénybe vesznek-e ilyen módszereket. Egy dán felmérés szerint tumoros betegekkel dolgozó ápolók 32\%-a ajánlotta a betegeknek az alternatív gyógymódok használatát, a klinikai munka során 20\%-uk használta is ezeket, és $53 \%$-uk ki is próbált valamilyen természetgyógyászati módszert [22]. Az Egyesült Királyságban készült felmérés szerint az ápolók 74\%-a ajánlotta a CAM-módszereket, és $80 \%$-uk vett már igénybe ilyen módszereket saját panasz esetén [23]. Koreában a szakdolgozók 44,5\%-a már vett igénybe komplementer terápiás gyógymódot [24]. Felmérésünkben a válaszadók $55,5 \%$-a - saját maga vagy családtagjai - vettek már igénybe természetgyógyászatot betegség vagy panasz esetén. A felmértek és családtagjaik a különféle típusú természetgyógyászati eljárásokat nagyon eltérő - 4,2-22,7\%-os - gyakorisággal vették igénybe. Vizsgálatunkból arra nem derülhetett fény, hogy az eljárások közül melyeket és miért preferálták; arra az ellentmondásra pedig jelenleg végképp nincs magyarázatunk, hogy miért épp a saját maguk által is tudományosan legkevésbé megalapozottnak tartott homeopátiát alkalmazták a legtöbben (a válaszadók 22,7\%-a). Ennek a feltúnő ellentmondásnak az okait kiegészító vizsgálat tárhatná fel.

\section{Tanulási kedv és klinikai alkalmazás}

Fontos kérdésnek tartottuk, hogy a pozitív attitüd és érdeklődés társul-e tanulási kedvvel, ezt milyen tényezők befolyásolják, illetve a szakdolgozók alkalmaznának-e ilyen módszereket megfeleló képzettség esetén. A komplementer terápiás gyógymódokkal kapcsolatos pozitív attitűd betegek és orvosok között is jellemzően kapcsolható a fiatal és középkorú, magasan képzett hölgyekhez [25-28]. Svédországban az egészségügyi dolgozók 55,8\%-a tanulna szívesen CAM-t [29]. Egy hongkongi felmérés alapján a nővérek 93,6\%-a tanulni szeretne a természetgyógyászati módszerekről, és 71,9\%-uk szerint a nem konvencionális gyógyászatot integrálni kellene a nyugati típusú orvoslásba [30]. Egy koreai vizsgálat szerint a szakdolgozók 32,3\%-a tanult már valamilyen CAM-módszert, 6,5\%-uk használt is ilyet a napi gyakorlatban [31]. Felmérésünkben a szakdolgozók 60,5\%-a szívesen tanulna komplementer terápiás gyógymódokat. A tanulási kedvet az életkor vagy a végzettség foka nem befolyásolta. A válaszadók 16,8\%-a alkalmazott már a napi munka során és 70,6\%-uk a jövőben szívesen alkalmazna természetgyógyászatot: ennek szignifikánsan magasabb az esélye, amennyiben a szakdolgozó vagy családtagjai a személyes életükben vettek már igénybe CAM-t.

\section{Integratín medicina}

A modern és a komplementer terápiás gyógymódok kombinált használatát integratív orvoslásnak nevezzük. Ennek alkalmazása számos gyakorlati és elméleti problémát, kérdést vet fel az ápolók napi munkájában [32]. Az Egyesült Államokban végzett vizsgálatok szerint az ápolóhallgatók 82\%-a támogatta az integratív medicina alkalmazását, és vizsgálták a diplomás ápolók curriculumába épített CAM-képzés hatékonyságát $[33,34]$. Egy kaliforniai felmérés szerint a CAM-módszereknek fontos szerepük lehetne a nővérmunka részeként a fájdalommenedzsment során, elsősorban hát-, nyak- és ízületi fájdalmak esetén. Ezt a munkát hatékonyabbá lehetne tenni a szakdolgozók CAM-mel kapcsolatos ismereteinek bővítésével, illetve ezek gyakorlati alkalmazásával [35]. Törökországban a diplomásápoló-hallgatók 57,7\%-a támogatta a komplementer terápiás gyógymódok klinikai alkalmazását, míg az orvostanhallgatók mindössze 32,6\%-a [36]. Saját eredményünk szerint a szakdolgozók $79,8 \%$-a támogatná az integratív gyógyítómunka bevezetését.

\section{Az egyes gyógymódok megitélése}

Mindenekelőtt érdemes megvizsgálnunk, hogy a modern nyugati orvoslás, az evidence-based medicine (EBM) követelményeinek mely módszerek felelnek meg. Számos kutatás alapján néhány komplementer és alternatív gyógymód az EBM kritériumai szerint is hatékony lehet, akár a perioperatív időszakban is. A hagyományos kínai orvoslás módszereit (akupunktúra, akupresszúra, fülakupunktúra) jó szorongásoldónak találták [37], hasznosak lehetnek intra- és posztoperatív fájdalomcsillapítás szempontjából [38-40], eredményesen megelőzhető és kezelhető e módszerekkel a posztoperatív hányinger és hányás [41]. A homeopátiás szereket több tanulmány vizsgálta, elsősorban ortopédiai mútétek utáni fájdalomcsillapítás szempontjából, ám nem találták a készítményeket effektív analgetikumnak, bár a posztoperatív duzzanatot csökkenthetik $[42,43]$. A manuálterápiát hasznosnak találták CABG-mútét utáni fájdalomcsillapításban és a mútét utáni légúti szövődmények megelőzésében $[44,45]$. A masszázs alkalmazható a szorongás csökkentésében, segíti a posztoperatív fájdalomcsillapítást és alkalmazható az intenzív terápia során is [46-49]. A kineziológia eredményes módszer az emlőmútét utáni lymphoedema megelőzésében [50]. A gyógynövények alkalmazása a perioperatív időszakban kétélú fegyver. Egyes gyógynövények segíthetnek a posztoperatív időszakban a bélmotilitás beindulásában $[51,52]$, a gyömbér jól használható PONV kezelésére [53]. A perioperatív időszakban a betegek által igénybe vett gyógynövény-terápia azonban a lehetséges gyógyszer-interakciók miatt számos szövődmény kiváltó oka lehet [54]: növelhetik a vérzésveszélyt, emelhetik a vérnyomást [55], az endokrin- és elektrolit-háztartás zava- 
rait idézhetik elő, potenciálisan hepatotoxicusak [56], megnyújthatják az anesztetikumok hatásidejét [57].

A komplementer gyógymódokkal kapcsolatos - erősebb vagy gyengébb - evidenciák ismeretében érdemes megvizsgálni, hogy a világ más részein hogy viszonyul az ápolószemélyzet e módszerekhez, hogy reálisan tudjuk értékelni saját eredményeinket. Egy Ausztráliában készült szakdolgozói felmérés szerint az ápolók 74\%-a vett igénybe az előző egy évben saját panaszai esetén komplementer terápiás gyógymódokat, 38\% alkalmazott ilyet betegei ápolása kapcsán is: a relaxáció $(21,3 \%)$, aromaterápia $(19,5 \%)$, masszázs $(6,7 \%)$, fitoterápia $(4,6 \%)$ és reflexológia $(4,5 \%)$ volt a legnépszerúbb [58]. Az Egyesült Államokban, sürgősségi osztályokon dolgozó ápolók között készült felmérések szerint a szakdolgozók érdeklődtek a CAM-gyógymódok iránt és fontosnak tartanák, ha a betegellátásban elérhetőbbek lennének e gyógymódok. Nyitottak a CAM-módszerek használatára, amelyek közül elsősorban a torna- és masszázsmódszereket, relaxációt, diétákat, illetve a fitoterápiát $(23,3 \%)$, kiropraktikát $(18,2 \%)$, akupresszúrát $(15,5 \%)$, homeopátiát $(10,7 \%)$, akupunktúrát $(6,7 \%)$ használták és javasolták. Fontosnak tartanák az elérhető oktatást, hiszen a betegek és a hozzátartozók is igénylik e gyógymódokat $[59,60]$. Hasonló következtetésre jutottak intenzív osztályos nővérek között végzett felmérés kapcsán is [61]. A fenti tanulmányok szerint egyértelmú kapcsolat van a személyes és klinikai alkalmazás között, tehát amennyiben egy ápoló igénybe vett CAM-módszereket, szignifikánsan gyakrabban javasolta ezeket a gyógymódokat betegeinek is, amely megfelelt már ismertetett eredményünknek is. Ausztráliában, intenzív osztályon dolgozó nővérek a torna- és masszázsfajtákat tartják a legelfogadhatóbb komplementer módszereknek betegeiknél [62]. Saját eredményeink szerint a legnépszerúbb és leginkább ajánlott gyógymódok a homeopátia, alternatív masszázs- és mozgásterápia, az akupunktúra és a manuálterápia voltak. A homeopátia végletes megítélésének kérdésére fentebb már utaltunk.

\section{Következtetés}

Vizsgálatunk a Semmelweis Egyetem egészségügyi szakdolgozóinak felmérésével kívánta bemutatni, hogy a perioperatív ellátásban dolgozó ápolószemélyzet milyen ismeretekkel és attitűddel rendelkezik a komplementer terápiás gyógymódokkal kapcsolatban.

Felmérésünk korlátai ellenére is úttörő, hiszen Magyarországon ilyen vizsgálat, tudomásunk szerint, még nem készült.

Eredményeink alapján elmondható, hogy bár saját értékelésük szerint kevés ismerettel rendelkeznek a természetgyógyászatról, a szakdolgozók érdeklődőek e terület iránt, szívesen bővítenék ismereteiket, bizonyos esetben alkalmaznák e módszereket, és támogatnák az integratív medicina bevezetését a betegellátásba.
Anyagi támogatás: A közlemény megírása és a kapcsolódó kutatómunka anyagi támogatásban nem részesült.

Szerzői munkamegosztás: S. S. Á.: A vizsgálat szervezése, statisztikai elemzés. A hipotézisek kidolgozásában és a kézirat megszövegezésében minden szerző egyenlő arányban vett részt. A cikk végleges változatát valamenynyi szerző elolvasta és jóváhagyta.

Érdekeltségek: A szerzőknek nincsenek érdekeltségeik.

\section{Köszönetnyilvánítás}

Köszönet illeti Gacsalné Kovács Editet a felmérés szervezésében nyújtott segítségéért, továbbá mindenkit, aki a kérdőív kitöltésével segítette a vizsgálat kivitelezését.

\section{Irodalom}

[1] Dobozy, A., Kerpel-Fronius, S., Komoly, S., et al.: Complementary medicine - built upon the principles of evidence-based therapy. Discussed and accepted by the Medical Section of the Hungarian Academy of Sciences. [Komplementer medicina - a bizonyítékokon alapuló orvoslás elvei alapján. A Magyar Tudományos Akadémia Orvosi Tudományok Osztályának állásfoglalása.] Orv. Hetil., 2011, 152(30), 1197-1204. [Hungarian]

[2] Eisenberg, D. M., Davis, R. B., Ettner, S. L., et al.: Trends in alternative medicine use in the United States, 1990-1997: results of a follow-up national survey. JAMA, 1998, 280(18), 1569-1575.

[3] Ernst, E.: Prevalence of use of complementary/alternative medicine: a systematic review. Bull. World Health Organ., 2000, $78(2), 252-257$.

[4] Horneber, M., Bueschel, G., Dennert, G., et al.: How many cancer patients use complementary and alternative medicine: a systematic review and metaanalysis. Integr. Cancer Ther., 2012, 11(3), 187-203.

[5] Bahall, M.: Complementary and alternative medicine usage among cardiac patients: a descriptive study. BMC Complement. Altern. Med., 2015, 15, 100.

[6] Waterbrook, A. L., Southall, J. C., Strout, T. D., et al.: The knowledge and usage of complementary and alternative medicine by emergency department patients and physicians. J. Emerg. Med., 2010, 39(5), 569-575.

[7] Soós, S. Á., Jeszenői, N., Darvas, K., et al.: Herbal medicine use by surgery patients in Hungary: a descriptive study. BMC Complement. Altern. Med., 2015, 15, 358.

[8] Kaye, A. D., Clarke, R. C., Sabar, R., et al.: Herbal medicines: current trends in anesthesiology practice - a hospital survey. J. Clin. Anesth., 2000, 12(6), 468-471.

[9] Skinner, C. M., Rangasami, J.: Preoperative use of herbal medicines: a patient survey. Br. J. Anaesth., 2002, 89(5), 792-795.

[10] American Society of Anesthesiologists: What you should know about your patients' use of herbal medicines. Available from: http://www.wehealny.org/services/BI_Anesthesiology/herbPatient.pdf

[11] Christina, J., Abigail, W., Cutbbertson, L. A.: Nurses' knowledge and attitudes toward complementary therapies for cancer: A review of the literature. Asia Pac. J. Oncol. Nurs., 2016, 3(3), 241-251.

[12] DeKeyser, F. G., Bar Cohen, B., Wagner, N.: Knowledge levels and attitudes of staff nurses in Israel towards complementary and alternative medicine. J. Adv. Nurs., 2001, 36(1), 41-48.

[13] Leach, M. J.: Public, nurse and medical practitioner attitude and practice of natural medicine. Complement. Ther. Nurs. Midwifery, 2004, 10(1), 13-21. 
[14] Decree No. 11 of 1997 (V. 28) NM of the Ministry of Welfare concerning certain fields of naturopath activity. [11/1997. (V. 28.) NM rendelet a természetgyógyászati tevékenység gyakorlásának egyes kérdéseirôl.] Available from: http://net.jogtar. $\mathrm{hu} / \mathrm{jr} / \mathrm{gen} / \mathrm{hjegy}$ doc.cgi?docid=99700011.NM [Hungarian]

[15] Brown, J., Cooper, E., Frankton, L., et al.: Complementary and alternative therapies: survey of knowledge and attitudes of health professionals at a tertiary paediatric/women's care facility. Complement Ther. Clin. Pract., 2007, 13(3), 194-200

[16] Chu, F. Y., Wallis, M.: Taiwanese nurses' attitudes towards and use of complementary and alternative medicine in nursing practice: a cross-sectional survey. Int. J. Nurs. Stud., 2007, 44(8), 1371-1378.

[17] Chang, M. Y., Lin, H. S., Tsai, C. F.: Student nurses' knowledge, attitude, and behavior toward chinese medicine and related factors. J. Nurs. Res., 2004, 12(2), 103-118.

[18] Shorofi, S. A., Arbon, P.: Nurses' knowledge, attitudes, and professional use of complementary and alternative medicine (CAM): a survey at five metropolitan hospitals in Adelaide. Complement. Ther. Clin. Pract., 2010, 16(4), 229-234.

[19] Jang, E. H., Park, K. S.: A comparative study of nurses and physicians' attitudes about complementary and alternative therapy. J. Korean Acad. Adult Nurs., 2003, 15(3), 402-410.

[20] Soós, S. Á., Eöry, A., Eöry, A., et al.: Complementary and alternative medicine from the primary care physicians' viewpoint. [Nem konvencionális gyógymódok a háziorvos szemszögébőll.] Orv. Hetil., 2015, 156(28), 1133-1139. [Hungarian]

[21] Soós, S. Á., Jeszenói, N., Darvas, K., et al.: Complementary and alternative medicine: attitudes, knowledge and use among surgeons and anaesthesiologists in Hungary. BMC Complement. Altern. Med., 2016, 16(1), 443.

[22] Damkier, A., Elverdam, B., Glasdam, S., et al.: Nurses' attitudes to the use of alternative medicine in cancer patients. Scand. J. Caring Sci., 1998, 12(2), 119-126.

[23] Buchan, S., Shakeel, M., Trinidade, A., et al.: The use of complementary and alternative medicine by nurses. Br. J. Nurs., 2012, 21(11), 672-674., 676 .

[24] Yom, Ү. H., Lee, K. E.: A comparison of the knowledge of, experience with and attitudes towards complementary and alternative medicine between nurses and patients in Korea. J. Clin. Nurs., 2008, 17(19), 2565-2572.

[25] Eisenberg, D. M., Kessler, R. C., Foster, C., et al.: Unconventional medicine in the United States. Prevalence, costs, and patterns of use. N. Engl. J. Med., 1993, 328(4), 246-252.

[26] Lucenteforte, E., Gallo, E., Pugi, A., et al.: Complementary and alternative drugs use among preoperative patients: a cross-sectional study in Italy. Evid. Based Complement., Alternat. Med., 2012, 2012, 527238

[27] Leung, J. M., Dzankic, S., Manku, K., et al.: The prevalence and predictors of the use of alternative medicine in presurgical patients in five California hospitals. Anesth. Analg., 2001, 93(4), 1062-1068.

[28] Giannelli, M., Cuttini, M., Da Frè, M., et al.: General practitioners' knowledge and practice of complementary/alternative medicine and its relationship with life-styles: A population-based survey in Italy. BMC Fam. Pract., 2007, 8, 30.

[29] Bjerså, K., Stener Victorin, E., Fagevik Olsén, M.: Knowledge about complementary, alternative and integrative medicine (CAM) among registered health care providers in Swedish surgical care: a national survey among university hospitals. BMC Complement. Altern. Med., 2012, 12, 42.

[30] Holroyd, E., Zhang, A. L., Suen, L. K., et al.: Beliefs and attitudes towards complementary medicine among registered nurses in Hong Kong. Int. J. Nurs. Stud., 2008, 45(11), 1660-1666.

[31] Son, H. M.: Nurses' perceptions and experiences with complementary and alternative therapies. J. Korean Acad. Fundam. Nurs., 2001, 8(3), 314-323.
[32] Shuval, J.: Nurses in alternative health care: integrating medical paradigms. Soc. Sci. Med., 2006, 63(7), 1784-1795.

[33] Melland, H. I., Clayburgh, T. L.: Complementary therapies: introduction into a nursing curriculum. Nurse Educ., 2000, 25(5), 247-2550.

[34] Booth-Laforce, C., Scott, C. S., Heithemper, M. M., et al.: Complementary and Alternative Medicine (CAM) attitudes and competencies of nursing students and faculty: results of integrating CAM into the nursing curriculum. J. Prof. Nurs., 2010, 26(5), 293-300.

[35] Trail-Mahan, T., Mao, C. L., Bawel-Brinkley, K.: Complementary and alternative medicine: Nurses' attitudes and knowledge. Pain Manag. Nurs., 2013, 14(4), 277-286.

[36] Yildirim, Y., Parlar, S., Eyigor, S., et al.: An analysis of nursing and medical students' attitudes towards and knowledge of complementary and alternative medicine (CAM). J. Clin. Nurs., 2010, 19(7-8), 1157-1566.

[37] Wang, S. M., Peloquin, C., Kain, Z. N.: The use of auricular acupuncture to reduce preoperative anxiety. Anesth. Analg., 2001, 93(5), 1178-1180

[38] Sun, Y., Gan, T. J., Dubose, J. W., et al.: Acupuncture and related techniques for postoperative pain: a systematic review of randomized controlled trials. Br. J. Anaesth., 2008, 101(2), 1511560 .

[39] Taghavi, R., Tabasi, K. T., Mogharabian, N., et al.: The effect of acupuncture on relieving pain after inguinal surgeries. Korean J. Pain, 2013, 26(1), 46-50.

[40] Tsao, G. J., Messner, A. H., Seybold, J., et al.: Intraoperative acupuncture for posttonsillectomy pain: a randomized, doubleblind, placebo-controlled trial. Laryngoscope, 2015, 125(8), 1972-1978.

[41] Holmér Pettersson, P., Wengström, Y.: Acupuncture prior to surgery to minimise postoperative nausea and vomiting: a systematic review. J. Clin. Nurs., 2012, 21(13-14), 1799-1805.

[42] Barlow, T., Downham, C., Barlow, D.: The effect of complementary therapies on post-operative pain control in ambulatory knee surgery: a systematic review. Complement. Ther. Med., 2013, $21(5), 529-534$

[43] Singer, S. R., Amit-Kohn, M., Weiss, S., et al.: Traumeel $S^{\circledR}$ for pain relief following hallux valgus surgery: a randomized controlled trial. BMC Clin. Pharmacol., 2010, 10, 9.

[44] Roncada, G.: Effects of osteopathic treatment on pulmonary function and chronic thoracic pain after coronary artery bypass graft surgery (OstinCaRe): study protocol for a randomised controlled trial. BMC Complement. Altern. Med., 2016, 16(1), 482 .

[45] Noll, D. R., Degenhardt, B. F., Fossum, C., et al.: Clinical and research protocol for osteopathic manipulative treatment of elderly patients with pneumonia. J. Am. Osteopath. Assoc., 2008, $108(9), 508-516$.

[46] Wang, H. L., Keck, J. F.: Foot and hand massage as an intervention for postoperative pain. Pain Manag. Nurs., 2004, 5(2), 5965 .

[47] Hill, C. F.: Is massage beneficial to critically ill patients in inten sive care units? A critical review. Intensive Crit. Care Nurs., 1993, 9(2), 116-121.

[48] Boitor, M., Martorella, G., Arbour, C., et al.: Evaluation of the preliminary effectiveness of hand massage therapy on postoperative pain of adults in the intensive care unit after cardiac surgery: a pilot randomized controlled trial. Pain Manag. Nurs., 2015, $16(3), 354-366$

[49] Miller, J., Dunion, A., Dunn, N., et al.: Effect of a brief massage on pain, anxiety, and satisfaction with pain management in postoperative orthopaedic patients. Orthop. Nurs., 2015, 34(4), 227-234.

[50] Malicka, I., Rosseger, A., Hanuszkiewicz, J., et al.: Kinesiology taping reduces lymphedema of the upper extremity in women 
after breast cancer treatment: a pilot study. Prz. Menopauzalny, $2014,13(4), 221-226$.

[51] Yoshikawa, K., Shimada, M., Wakabayashi, G., et al.: Effect of Daikenchuto, a traditional Japanese herbal medicine, after total gastrectomy for gastric cancer: A multicenter, randomized, double-blind, placebo-controlled, phase II trial. J. Am. Coll. Surg., 2015, 221(2), 571-578.

[52] Yang, B., Xu, F. Ү., Sun, H. J., et al.: Da-Cheng-Qi decoction, a traditional Chinese herbal formula, for intestinal obstruction: systematic review and meta-analysis. Afr. J. Tradit. Complement. Altern. Med., 2014, 11(4), 101-119.

[53] Marx, W., Kiss, N., Isenring, L.: Is ginger beneficial for nausea and vomiting? An update of the literature. Curr. Opin. Support. Palliat. Care, 2015, 9(2), 189-195.

[54] Tsen, L. C., Segal, S., Pothier, M., et al.: Alternative medicine use in presurgical patient. Anesthesiology, 2000, 93(1), 148-151.

[55] Jalili, J., Askeroglu, U., Alleyne, B., et al.: Herbal products that may contribute to hypertension. Plast. Reconstr. Surg., 2013, 131(1), 168-173.

[56] Miller, L. G.: Herbal medicinals: selected clinical considerations focusing on known or potential drug-herb interactions. Arch. Intern. Med., 1998, 158(20), 2200-2211.
[57] Almeida, J. C., Grimsley, E. W.: Coma from the health food store: interaction between kava and alprazolam. Ann. Intern. Med., 1996, 125(11), 940-941.

[58] Wilkinson, J. M., Simpson, M. D.: Personal and professional use of complementary therapies by nurses in NSW, Australia. Complement. Ther. Nurs. Midwifery, 2002, 8(3), 142-147.

[59] Tracy, M. F., Lindquist, R., Savik, K., et al.: Use of complementary and alternative therapies: a national survey of critical care nurses. Am. J. Crit. Care, 2005, 14(5), 404-414.

[60] Lindquist, R., Tracy, M. F., Savik, K., et al.: Regional use of complementary and alternative therapies by critical care nurses. Crit. Care Nurse, 2005, 25(2), 63-75.

[61] Tracy, M. F., Lindquist, R., Watanuki, S., et al.: Nurse attitudes towards the use of complementary and alternative therapies in critical care. Heart Lung, 2003, 32(3), 197-209.

[62] Cooke, M., Mitchell, M., Tiralongo, E., et al.: Complementary and alternative medicine and critical care nurses: A survey of knowledge and practices in Australia. Aust. Crit. Care, 2012, 25(4), 213-223.

(Soós Sándor Árpád dr., Budapest, Üllői út 78., 1082 e-mail: soossandormd@gmail.com)

\section{Ellen Notbohm-Veronica Zysk} EZEREGY NAGYSZERRUU ÖTLET

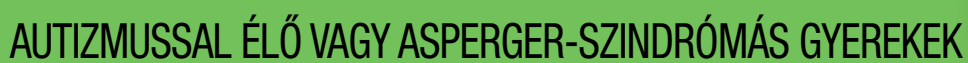
NEVELÉSÉHEZ ÉS TANÍTÁSÁHOZ

„Ha minden iskolában és családban a könyvben szereplő ötletek kis töredékét felhasználnák, beláthatatlan lehetöségek nyilinának meg elöttünk, hogy javítsuk az autizmussal vagy Asperger-szindrómával élö gyermekek életminöségét. Ez pedig csodálatos dolog!"

A könyv számtalan azonnal alkalmazható ötletet kínál szülőknek és nevelőknek az alábbi területeken:

- szenzoros integráció: fejlesztőfeladatok a szabadban és bent,

- kommunikáció: szóhasználat, hallás, vizualitás, környezet,

- viselkedés: tipikus viselkedési formák és kezelésük,

- mindennapi élet: ötletek a mindennapi szituációkhoz, a biztonság megteremtéséhez,

- szociális létezés: barátság, játék, kooperáció, érzelmek.

Dr. Temple Grandin

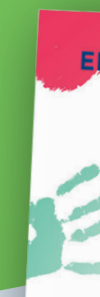
ELLEN NOTBOHM-VERONICA ZYSK IER
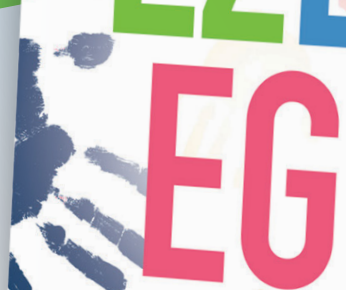

NAGYSZERÜ ÖTLET AUTIZMUSSAL ÉLÖ vagy ASPERGER-SZINDRÓMÁS GYEREKE

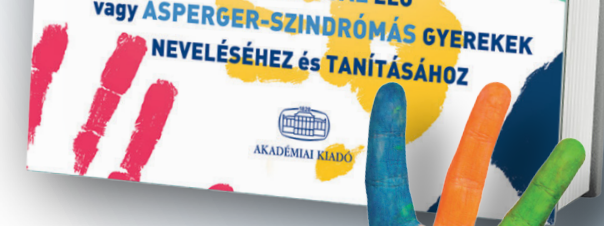

